\title{
Effect of quercetin or butylated hydroxytoluene on cooled or frozen-thawed ram sperm quality
}

\section{Efeito da inclusão de quercetina ou butil-hidroxitolueno na qualidade do sêmen de carneiro resfriado ou congelado}

\author{
Lucas Emanuel Ferreira Canuto ${ }^{1 *}$; Lorenzo Garrido Teixeira Martini Segabinazzi"; \\ Endrigo Adonis Braga de Araújo "; Luis Fernando Mercês Chaves Silva"; \\ Sidnei Nunes de Oliveira ${ }^{1}$; Felipe Morales Dalanezi'; José Antonio Dell'Aqua \\ Junior'2; Frederico Ozanam Papa²; Eunice Oba²
}

Highlights

The inclusion of quercetin did not affect sperm motility parameters.

The inclusion of BHT did not affect sperm motility parameters.

The ram's breed did not affect sperm volume and total sperm number.

\begin{abstract}
Cooling and freezing processes cause physical and chemical damage to sperm by cold shock and oxidative stress. This study aimed to evaluate the effect of two antioxidants on sperm parameters of cooled and frozen-thawed ram semen diluted in an egg yolk-based extender. Semen was collected from 30 rams and processed in two consecutive experiments to test the inclusion of different concentrations of quercetin and butylated hydroxytoluene (BHT) in an egg yolk-based semen extender. Dimethyl sulfoxide (DMSO) was added as a solvent to the semen extender in a ratio of $1 \mathrm{~mL}$ DMSO for $90 \mathrm{mg}$ of quercetin and $1 \mathrm{~mL}$ DMSO for $880 \mathrm{mg}$ of $\mathrm{BHT}$. After collection, semen was diluted at $200 \times 10^{6} \mathrm{motile} \mathrm{sperm} / \mathrm{mL}$ (control) and split into different groups in each experiment. In experiment 1 , semen was diluted with the extender containing quercetin (Q5, $5 \mu \mathrm{g} / \mathrm{mL} ;$ Q10, $10 \mu \mathrm{g} / \mathrm{mL} ; \mathrm{Q} 15,15 \mu \mathrm{g} / \mathrm{mL}$ ) or DMSO alone (DMSO1, $0.055 \mu \mathrm{L}$ DMSO per mL; DMSO2, $0.165 \mu \mathrm{L}$ DMSO per $\mathrm{mL}$ ). In experiment 2, semen was diluted with the extender with BHT (BHT1, 0.5 $\mu \mathrm{g} / \mathrm{mL} ; \mathrm{BHT} 2,1 \mu \mathrm{g} / \mathrm{mL}$; BHT3, $1.5 \mu \mathrm{g} / \mathrm{mL}$ ) or DMSO alone (DMSO3, $0.375 \mu \mathrm{L}$ DMSO per mL; DMSO4, 1.125 $\mu \mathrm{L}$ DMSO per $\mathrm{mL}$ ). After dilution, the semen was divided into two aliquots. Treated ram sperm samples were also subjected to different storage methods. The first set of samples was cooled at $5^{\circ} \mathrm{C}$ for $24 \mathrm{~h}$, whereas the second set of samples was frozen-thawed. Sperm motility parameters and plasma membrane integrity (PMI) were evaluated immediately after dilution (Oh) and $24 \mathrm{~h}$ after cooling and in the frozen-thawed samples

1 Students Post Graduate, Universidade Estadual de São Paulo, UNESP, School of Veterinary Medicine and Animal Science, Botucatu, SP, Brazil. E-mail: lucas.canuto@unesp.br; Igseg@hotmail.com; endrigoadonis.vet@gmail.com; luisfernando.mchaves@gmail.com; sidmev@hotmail.com; fmdalanezi@gmail.com

2 Profs., UNESP, School of Veterinary Medicine and Animal Science, Botucatu, SP, Brazil. E-mail: dellaquajunior@uol. com.br; papa@fmvz.unesp.br; eunice.oba@unesp.br

* Author for correspondence
\end{abstract}

Received: Aug. 25, 2021 - Approved: Dec. 15, 2021 
via computer-assisted sperm analysis and epifluorescence microscopy, respectively. The inclusion of quercetin or BHT did not affect sperm motility parameters or PMI of fresh, cooled, or frozen-thawed sperm in this study $(P<0.05)$. However, further studies are needed to test the effects of these antioxidants on the fertility of cryopreserved ram semen.

Key words: Antioxidant. Cryopreservation. Oxidative damage. Lipid peroxidation. Small ruminants. Sheep.

\section{Resumo}

O resfriamento e o congelamento causam danos físicos e químicos aos espermatozoides por choque térmico e estresse oxidativo. Portanto, este estudo teve como objetivo avaliar o efeito da inclusão de dois antioxidantes em um diluente à base de gema de ovo sobre os parâmetros espermáticos do sêmen ovino resfriado e congelado. Trinta carneiros tiveram o sêmen coletado e processado em dois experimentos consecutivos para testar a inclusão de diferentes concentrações de quercetina e hidroxitolueno butilado (BHT) em diluente de sêmen à base de gema de ovo. O DMSO foi adicionado como solvente ao diluente de sêmen em uma proporção de $1 \mathrm{~mL}$ de DMSO parra $90 \mathrm{mg}$ de quercetina e $1 \mathrm{Ml}$ de DMSO para $880 \mathrm{mg}$ de BHT. Após a coleta, o sêmen foi diluído a $200 \times 10^{6}$ espermatozoides móveis $/ \mathrm{mL}$ (Controle) e dividido em diferentes grupos em cada experimento. Experimento 1, Quercetina (Q5, $5 \mu \mathrm{g} / \mathrm{mL} ; \mathrm{Q} 10,10 \mu \mathrm{g} / \mathrm{mL} ; \mathrm{Q} 15,15$ $\mu \mathrm{g} / \mathrm{mL}$ ) ou DMSO (DMSO1, 0,055 $\mu \mathrm{L}$ de DMSO por ml; DMSO2, 0,165 $\mu \mathrm{L}$ de DMSO / $\mathrm{mL}$ ) foram adicionados ao extensor. Experimento 2, BHT (BHT1, 0,5 $\mu \mathrm{g} / \mathrm{mL} ; \mathrm{BHT} 2,1 \mu \mathrm{g} / \mathrm{mL} ; \mathrm{BHT3}, 1,5 \mu \mathrm{g} / \mathrm{mL}$ ) ou DMSO (DMSO3, $0,375 \mu \mathrm{L}$ de DMSO por ml; DMSO4, 1,125 $\mu \mathrm{L}$ de DMSO / $\mathrm{mL}$ ) foram adicionados à o extensor. Após a diluição, o sêmen foi dividido em duas alíquotas. O primeiro foi resfriado a $5^{\circ} \mathrm{C}$ por $24 \mathrm{~h}$, enquanto o segundo foi congelado. Os parâmetros de motilidade espermática e integridade da membrana plasmática (PMI) foram avaliados, imediatamente após a diluição $(\mathrm{Oh})$ e $24 \mathrm{~h}$ após o resfriamento e nas amostras congeladas, pelo CASA e microscopia de epifluorescência, respectivamente. A inclusão de quercetina ou BHT não afetou os parâmetros de motilidade espermática e PMI de espermatozoides frescos, resfriados ou congelados $(P$ $<0,05)$. Portanto, a inclusão de quercetina e BHT não beneficiou os parâmetros espermáticos do sêmen ovino submetido a armazenamento líquido a $5^{\circ} \mathrm{C}$ por $24 \mathrm{~h}$ ou protocolo de congelamento no presente estudo. No entanto, mais estudos são necessários para testar o efeito desses antioxidantes na fertilidade do sêmen ovino criopreservado.

Palavras-chave: Antioxidante. Criopreservação dano oxidativo. Peroxidação lipídica. Pequenos ruminantes. Ovinos.

\section{Introduction}

Semen cryopreservation plays an essential tool for conserving and distributing desirable genetic material over long distances. However, cooling and freezing cause physical and chemical damage to the sperm by cold shock and oxidative stress (Budai, Egerszegi, Olah, Javor, \& Kovacs, 2014). Cold shock is associated with irreversible changes in the plasma membrane and acrosome, DNA fragmentation, andreducedfertilizationcapacity (Budai et al., 2014; Salamon, \& Maxwell, 2000). During refrigeration and cryopreservation, sperms undergo a membrane phase transition and reorganization of the original lipid and protein composition, which causes a decrease in membrane fluidity and a higher 
predisposition to ruptures, compromising cell function (Parks, \& Lynch, 1992). Additionally, there is excessive production of oxygen-free radicals during sperm cooled-storage and freeze-thaw cycles (Budai et al., 2014). In rams, high reactive oxygen species (ROS) produced during cold storage affect sperm plasma membrane viability and mitochondrial function and reduce sperm motility (Allai et al., 2016; Amidi, Pazhohan, Shabani, Khodarahmian. \& Nekoonam, 2016). The interaction between excessive reactive oxygen species (ROS) produced by sperm metabolism and dead sperm with polyunsaturated fatty acids in the sperm membrane induces lipid peroxidation and reduces sperm quality (Budai et al., 2014). Interestingly, the plasma membrane of small ruminant sperm is rich in polyunsaturated fatty acids, which renders the sperm highly vulnerable to oxidative damage (Bucak et al., 2010).

Several antioxidants have been tested to ameliorate the effects of oxidative stress in cryopreserved sperms or in cooled storage. Quercetin is a flavonoid compound found in fruits and vegetables with antimicrobial (Nitiema, Savadogo, Simpore, Dianou, \& Traore, 2012), anti-inflammatory (Guardia, Rotelli, Juarez, \& Pelzer, 2001), and antioxidative (Gibb, Butler, Morris, Maxwell, \& Grupen, 2013; Ben, Zribi. \& Ammar-Keskes, 2011) properties. Quercetin scavenges ROS and hydroxyl radicals (Boots, Haenen \& Bast, 2008), and has been suggested as a potent antioxidant for the cryopreservation of semen from stallions, rats, rooster, and dogs (Gibb et al., 2013; Ben et al., 2011; Appiah et al., 2020; Kawasaki et al., 2020). Another antioxidant added to semen extenders to minimize sperm damage caused by oxidative stress and cold shock is butylated hydroxytoluene (BHT) (Jara, Merino, Sánchez, \& Risopatrón, 2019;
Merino et al., 2015). Butylated hydroxytoluene is a synthetic analog of vitamin $E$ that reacts with peroxy radicals to transform them into hydroperoxides, interrupting the oxidative process (Seifi-Jamadi, Kohram, ZarehShahne, Dehghanizadeh, \& Ahmad, 2016). In a previous study, the addition of BHT at a concentration of $5.0 \mathrm{mM}$ improved sperm parameters of ram cryopreserved sperm (Palomo, García, \& Tabarez, 2017). Therefore, the present study hypothesizes that the addition of quercetin or BHT to a commercially available egg yolk-based semen extender (BotuBov ${ }^{\circledR}$ ) can increase the viability of ram sperm during the cooling and freezing processes. This study aimed to evaluate the effect of the inclusion of quercetin and $\mathrm{BHT}$ in a commercially available egg yolk-based extender on sperm parameters of cooled and frozen-thawed ram semen.

\section{Materials and Methods}

This study was approved by the Institutional Animal Care and Use Committee of São Paulo State University, Botucatu, São Paulo, Brazil, under protocol \#0180/2014. The study was conducted from March to June 2015. Thirty rams (15 Santa Inês breed and 15 Texel breed) ranging from 2 to 5 years old, clinically healthy, with a good body condition score and satisfactory sperm parameters (Table 1) were enrolled in this study (Oliveira, Oliveira, Lima, Andrade, Abreu, \& Oliveira, 2017; Mandiki, Derycke Bister, \& Paquay, 1988). The rams were kept on a farm in laras city, SP, Brazil $\left(22^{\circ} 52^{\prime} 15^{\prime \prime} \mathrm{S} 49^{\circ} 09^{\prime} 46^{\prime \prime} \mathrm{W}\right)$, and a total of 178 ejaculates were harvested and divided into two experiments, as described below. Rams were housed in $5 \times 3 \mathrm{~m}$ stalls, fed with alfalfa grass hay, and free access to water and trace minerals. 
Table 1

Seminal parameters of Santa Inês and Texel rams

\begin{tabular}{ccccccc} 
Rams & Volume & SC $\left(\times 10^{9} / \mathrm{mL}\right)$ & TM & PM & RAP & PMI \\
\hline Santa Ines & $1.0 \pm 0.3$ & $3.6 \pm 0.8$ & $88.4 \pm 4.6$ & $61.3 \pm 10.6$ & $81.2 \pm 6.5$ & $54.6 \pm 14.3$ \\
\hline Texel & $1.0 \pm 0.2$ & $3.4 \pm 0.4$ & $88.1 \pm 9.0$ & $60.6 \pm 10.2$ & $79.6 \pm 11.1$ & $57.2 \pm 13.1$ \\
Overall & $1.0 \pm 0.3$ & $3.5 \pm 0.6$ & $88.2 \pm 7.4$ & $60.9 \pm 10.2$ & $80.2 \pm 9.4$ & $56.1 \pm 13.4$
\end{tabular}

SC, sperm concentration; TM, total motility; PM, progressive motility; RAP, rapid sperm; PMI, plasma membrane integrity. All data are presented as the mean \pm SD.

Immediately before the study, all rams had two washout semen collections performed to deplete the old sperm reserves. Semen was harvested by electrostimulation (Eletrojet Premium, Eletrovet, Valinhos, SP, Brazil) The electroejaculation procedure involved a series of five pulses of similar voltage, each separated by an interval of $5 \mathrm{~s}$. The initial stimulus was $1 \mathrm{~V}$, and the maximum voltage was $9 \mathrm{~V}$ (Fidan, Yeni, Avdatek, Özçinar, \& Hazman, 2018). Semen was then collected in a $15 \mathrm{~mL}$ plastic tube covered by a thermal protector. The semen volume was recorded, and sperm concentration was assessed with a hemocytometer (Optik Labor, Lancing, England) using a phase-contrast microscope (Jenamed 2: Carl Zeiss, Munich, Germany) at $200 \times$ magnification. An aliquot of raw semen was diluted (1:100) in 10\% formol saline, and morphological characteristics were evaluated using a differential interference contrast microscope (Leica DM2500; Leica Microsystems, SP, Brazil) under 1000× magnification using oil immersion. Morphological characteristics were assessed in 100 sperms, and abnormalities of the head, midpiece, and tail were analyzed (Brito, 2007). Sperm motility parameters were evaluated using computer-assisted sperm analysis
(CASA; IVOS 11, Hamilton Thorne, Inc., Beverly, MA, USA). Ejaculates with the following minimum criteria were selected for the study: volume, $0.75-2 \mathrm{~mL}$; sperm concentration $>2.5$ $\times 10^{9} \mathrm{sperm} / \mathrm{mL}$; percentage of motile sperm $>70 \%$; less than $10 \%$ of morphologically abnormal cells.

After collection and initial analyses, semen was extended with a commercially available ram semen freezing extender (BotuBov ${ }^{\circledR}$, Botupharma, Botucatu, SP, Brazil) at $200 \times 10^{6}$ motile sperm $/ \mathrm{mL}$ and split into different groups in each experiment, as described below. After extension, the samples were stabilized for $20 \mathrm{~min}$ at room temperature $\left(22^{\circ} \mathrm{C}\right)$. Next, semen was loaded into $0.25 \mathrm{~mL}$ French straws (10 straws per group) and cooled (5 straws/group) or frozen (5 straws/group). For cooling, semen was stored in a passive semen cooling container (Botutainer, Botupharma, Brazil) at $5{ }^{\circ} \mathrm{C}$ for 24 h. For freezing, the straws were placed in a temperature-controlled refrigerator (Minitub do Brasil Ltda, Porto Alegre, Rio Grande do Sul, Brazil) at $5{ }^{\circ} \mathrm{C}$ for $240 \mathrm{~min}$. Afterwards, the straws were placed $4 \mathrm{~cm}$ above liquid nitrogen for 20 min and then plunged into liquid nitrogen and stored at $-196^{\circ} \mathrm{C}$ for further evaluation. 


\section{Sperm analyses}

Sperm motility parameters were evaluated by CASA using customized settings for ram sperm (Additional file: S-Table 1). For each sample, the percentiles of total motility (TM), progressive motility (PM), average path velocity (VAP, $\mu \mathrm{m} / \mathrm{s})$, straight-line velocity (VSL, $\mu \mathrm{m} / \mathrm{s})$, curvilinear velocity (VCL, $\mu \mathrm{m} / \mathrm{s})$, and rapid spermatozoa (RAP) were evaluated. Each sample was incubated in a dry bath at $37{ }^{\circ} \mathrm{C}$ for 10 min before each evaluation. An aliquot of $10 \mu \mathrm{L}$ was loaded into a Makler chamber (Irvine Scientific, Santa Ana, CA, USA) and a minimum of 1000 cells in five random fields were assessed.

The percentage of sperm with an intact plasma membrane (PMI) were assessed by epifluorescence microscopy (Leica Microsystems, DMLB, Germany) based on the association of fluorescence from propidium iodide (PI) and 6-carboxyfluorescein diacetate, as previously described (Harrison, R. A. P., \& Vickers, S. E., 1990). Carboxyfluorescein diacetate-positive cells were considered sperm with intact plasma membrane and $\mathrm{PI}$-positive sperm with damaged plasma membrane.

\section{Preparation of the extenders}

All chemicals used in this study were purchased from Sigma-Aldrich (St. Louis, MO, USA). A commercially available egg yolkbased semen freezing extender (BotuBov ${ }^{\circledR}$ ) was used for all tests, and quercetin or BHT were added according to the specified concentration. Since quercetin and BHT are poorly soluble in aqueous media, the addition of dimethyl sulfoxide (DMSO) as a solvent was required. DMSO was added at a ratio of $1 \mathrm{~mL}$ of DMSO to $90 \mathrm{mg}$ of quercetin and $1 \mathrm{~mL}$ of DMSO for 880 mg of BHT (Neagu et al., 2010).

Experiment 1 - Effect of quercetin on sperm parameters of ram semen subjected to cooling or freezing

Eighty-eight ejaculates (three of 28 rams and two of two rams) were harvested and used in this experiment. Each ejaculate was split into six aliquots of equal sperm concentration and extended at $200 \times 10^{6}$ motile sperm $/ \mathrm{mL}$ in BotuBov $^{\circledR}$ (Control) according to the concentration of quercetin (Q5, $5 \mu \mathrm{g} / \mathrm{mL} ;$ Q10, $10 \mu \mathrm{g} / \mathrm{mL} ; \mathrm{Q} 15,15 \mu \mathrm{g} /$ $\mathrm{mL}$ ) or DMSO (DMSO1, $0.055 \mu \mathrm{L}$ of DMSO per $\mathrm{ml}$; DMSO2, $0.165 \mu \mathrm{L}$ of $\mathrm{DMSO} / \mathrm{mL}$ ) added to the extender. Groups DMSO1 and DMSO2 correspond to the amount of DMSO used as a vehicle for quercetin in groups Q5 and Q15, respectively.

Experiment 2 - Effect of BHT on sperm parameters of ram semen subjected to cooling or freezing

Ninety ejaculates (three per ram) were harvested and used in this experiment. Each ejaculate was divided into six aliquots of equal concentration, and extended at $200 \times$ 106 motile sperm/mL in BotuBov ${ }^{\circledR}$ (Control) according to the concentration of $\mathrm{BHT}$ (BHT1, $0.5 \mu \mathrm{g} / \mathrm{mL}$; BHT2, $1 \mu \mathrm{g} / \mathrm{mL}$; BHT3, $1.5 \mu \mathrm{g} / \mathrm{mL}$ ) or DMSO (DMSO3, $0.375 \mu \mathrm{L}$ of DMSO per $\mathrm{ml}$; DMSO4, $1.125 \mu \mathrm{L}$ of $\mathrm{DMSO} / \mathrm{mL}$ ) that was added to the extender. Groups DMSO3 and DMSO4 correspond to the amount of DMSO used as a vehicle for $\mathrm{BHT}$ in groups $\mathrm{BHT} 1$ and BHT3, respectively. 


\section{Statistical analysis}

Data analyses were performed using the GraphPad Prism 8.0.1 (GraphPad Software, San Diego, California, USA). The Gaussian distribution was evaluated using the ShapiroWilk normality test. Semen parameters were assessed using ANOVA and Tukey's posthoc test. Ram was accounted as a random effect. Ejaculate order and time of storage in the extender were considered fixed effects. Significance was set at $P \leq 0.05$. All data are presented as the mean $\pm S D$.

\section{Results and Discussion}

The overall ejaculated volume, concentration, and total sperm ejaculation obtained in the present study are shown in Table 1. There were no effects of breed (Santa Ines vs. Texel) or ejaculate order ( $P>0.05)$, and rams displayed minimal variation in raw semen parameters (Table 1).
Experiment 1 - Effect of quercetin on sperm parameters of ram semen subjected to cooling or freezing

Sperm parameters were not different at $0 \mathrm{~h}$ among the groups $(\mathrm{P}>0.05$, Table $\mathrm{S} 1)$. In addition, there were no differences in motility parameters and PMI between fresh semen and semen cooled at $5{ }^{\circ} \mathrm{C}$ for $24 \mathrm{~h}(\mathrm{P}$ $>0.05)$. Sperm motility parameters and PMI in cooled and post-thawed semen extended with different concentrations of quercetin are shown in Tables 2 and 3, respectively. There was no effect of supplementation with quercetin or DMSO on the sperm parameters evaluated in the present experiment after cooling or freezing ram sperm using an egg yolk-based extender. There was a reduction in sperm parameters of frozen-thawed semen in all groups compared with pre-freezing sperm characteristics $(P<0.05)$.

\section{Table 2}

Parameters of ram sperm cooled for $24 \mathrm{~h}$ at $5^{\circ} \mathrm{C}$ in BotuBov ${ }^{\circledR}$ containing different concentrations of quercetin and DMSO

\begin{tabular}{|cccccccc|}
\hline & Control & Q5 & Q10 & Q15 & DMSO1 & DMSO2 & P value \\
\hline TM (\%) & $89.8 \pm 5.6$ & $89.6 \pm 5.6$ & $89.6 \pm 5.9$ & $89.7 \pm 4.0$ & $89.7 \pm 6.4$ & $88.9 \pm 6.8$ & 0.985 \\
\hline PM (\%) & $62.1 \pm 9.5$ & $60.2 \pm 10.5$ & $61.3 \pm 9.4$ & $62.3 \pm 9.6$ & $61.9 \pm 10.0$ & $61.7 \pm 9.0$ & 0.978 \\
\hline RAP (\%) & $80.4 \pm 9.4$ & $80.1 \pm 8.8$ & $79.3 \pm 9.5$ & $80.1 \pm 8.5$ & $80.8 \pm 10.0$ & $79.6 \pm 9.2$ & 0.979 \\
\hline VAP $(\mu \mathrm{m} / \mathrm{s})$ & $128.2 \pm 9.9$ & $126.7 \pm 9.2$ & $127.2 \pm 11.2$ & $128.4 \pm 10.8$ & $127.1 \pm 10.0$ & $125.2 \pm 9.3$ & 0.895 \\
\hline VSL $(\mu \mathrm{m} / \mathrm{s})$ & $106.9 \pm 22.4$ & $104.5 \pm 21.8$ & $109.9 \pm 11.9$ & $110.9 \pm 12.2$ & $109.9 \pm 10.1$ & $108.1 \pm 10.2$ & 0.867 \\
\hline VCL $(\mu \mathrm{m} / \mathrm{s})$ & $198.0 \pm 26.1$ & $200.8 \pm 25.9$ & $199.6 \pm 24.9$ & $201.1 \pm 24.4$ & $199.0 \pm 26.1$ & $194.8 \pm 25.9$ & 0.862 \\
\hline PMI $(\%)$ & $63.4 \pm 13.4$ & $58.7 \pm 14.8$ & $63.1 \pm 14.4$ & $57.3 \pm 19.5$ & $57.7 \pm 16.5$ & $55.6 \pm 13.9$ & 0.442 \\
\hline
\end{tabular}

TM, total motility; PM, progressive motility; VAP, average path velocity; VSL, velocity straight line; VCL, velocity curvilinear; RAP, rapid sperm; PMI, plasma membrane integrity. Control, egg yolk-based extender without quercetin (BotuBov $\left.{ }^{\circledR}\right) ; \mathrm{Q}$,

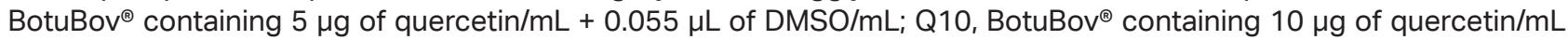
$+0.110 \mu \mathrm{L}$ of DMSO/mL; Q15, BotuBov ${ }^{\circledR}$ containing $15 \mu \mathrm{g}$ of quercetin/mL + 0.165 $\mu \mathrm{L}$ of DMSO/mL; DMSO1, BotuBov ${ }^{\circledR}$ containing $0.055 \mu \mathrm{L}$ of $\mathrm{DMSO} / \mathrm{mL}$; DMSO2, BotuBov ${ }^{\circledR}$ containing $0.165 \mu \mathrm{L}$ of $\mathrm{DMSO} / \mathrm{mL}$. All data are presented as the mean \pm SD. 


\section{Table 3}

\section{Sperm parameters of post-thawed ram sperm extended and frozen in BotuBov ${ }^{\circledR}$ containing different} concentrations of quercetin and DMSO

\begin{tabular}{|c|c|c|c|c|c|c|c|}
\hline & Control & Q5 & Q10 & Q15 & DMSO1 & DMSO2 & $P$ value \\
\hline TM (\%) & $69.5 \pm 10.4$ & $68.5 \pm 14.9$ & $71.2 \pm 12.8$ & $69.2 \pm 10.2$ & $63.0 \pm 15.9$ & $65.0 \pm 15.5$ & 0.420 \\
\hline PM (\%) & $38.9 \pm 9.4$ & $41.9 \pm 11.7$ & $41.9 \pm 11.7$ & $41.3 \pm 9.3$ & $37.1 \pm 10.0$ & $37.1 \pm 10.5$ & 0.451 \\
\hline RAP (\%) & $50.6 \pm 11.6$ & $52.4 \pm 15.5$ & $53.2 \pm 15.2$ & $51.6 \pm 12.5$ & $46.4 \pm 14.3$ & $48.2 \pm 13.8$ & 0.619 \\
\hline $\operatorname{VAP}(\mu \mathrm{m} / \mathrm{s})$ & $112.5 \pm 11.3$ & $108.4 \pm 24.5$ & $111.5 \pm 11.3$ & $110.6 \pm 12.0$ & $111.1 \pm 10.8$ & $109.9 \pm 10.6$ & 0.971 \\
\hline VSL $(\mu \mathrm{m} / \mathrm{s})$ & $97.8 \pm 11.8$ & $100.1 \pm 11.1$ & $97.5 \pm 10.6$ & $96.8 \pm 12.3$ & $97.9 \pm 9.9$ & $95.2 \pm 10.0$ & 0.839 \\
\hline VCL $(\mu \mathrm{m} / \mathrm{s})$ & $162.3 \pm 17.3$ & $164.2 \pm 14.2$ & $163.5 \pm 10.1$ & $164.4 \pm 15.2$ & $163.1 \pm 16.9$ & $164.6 \pm 14.7$ & 0.995 \\
\hline PMI (\%) & $25.8 \pm 9.8$ & $25.9 \pm 12.8$ & $27.4 \pm 11.6$ & $24.1 \pm 8.1$ & $24.5 \pm 13.3$ & $20.3 \pm 10.2$ & 0.384 \\
\hline
\end{tabular}

TM, total motility; PM, progressive motility; VAP, average path velocity; VSL, velocity straight line; VCL, velocity curvilinear; RAP, rapid sperm; PMI, plasma membrane integrity. Control, egg yolk-based extender without quercetin (BotuBov $\left.{ }^{\circledR}\right)$; Q5, $^{2}$

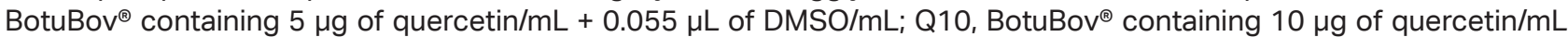
$+0.110 \mu \mathrm{L}$ of DMSO/mL; Q15, BotuBov ${ }^{\circledR}$ containing $15 \mu \mathrm{g}$ of quercetin $/ \mathrm{mL}+0.165 \mu \mathrm{L}$ of DMSO/mL; DMSO1, BotuBov ${ }^{\circledR}$ containing $0.055 \mu \mathrm{L}$ of $\mathrm{DMSO} / \mathrm{mL}$; DMSO2, BotuBov ${ }^{\circledR}$ containing $0.165 \mu \mathrm{L}$ of $\mathrm{DMSO} / \mathrm{mL}$. All data are presented as the mean \pm SD.

Experiment 2 - Effect of BHT on sperm parameters of ram semen subjected to cooling or freezing

Sperm parameters were not different at $0 \mathrm{~h}$ among the groups $(\mathrm{P}>0.05$, Table $\mathrm{S} 2)$. In addition, there were no differences in motility parameters and PMl between fresh semen and semen cooled at $5{ }^{\circ} \mathrm{C}$ for $24 \mathrm{~h}(\mathrm{P}$ $>0.05$ ). However, there was a reduction in sperm parameters of frozen-thawed semen in all groups compared with the pre-freezing sperm characteristics $(P<0.05)$. Sperm motility parameters and $\mathrm{PMI}$ in cooled and post-thawed semen extended with different concentrations of BHT are highlighted in Tables 4 and 5, respectively. There was no effect of supplementation with BHT or DMSO on the sperm parameters evaluated in the present experiment after cooling or freezing ram sperm using an egg yolk-based extender.

The overall ejaculated volume, sperm concentration, total sperm ejaculated, and sperm motility of the rams used in this study were consistent with those of other studies on Santa Ines and Texel sheep breeds (Oliveira et al., 2017; Mandiki et al., 1998). The inclusion of quercetin or BHT in the semen with a freezing egg yolk-based extender was tested for sperm motility and viability of either cooled or frozen-thawed ram semen. Although quercetin has been reported to improve postthawed sperm parameters of bulls (Avdatek et al., 2018; Tvrdá, Tušimová, Kováčik, Paál, \& Lukáč, 2016), horses (Seifi-Jamadi et al., 2016), roosters (Appiah et al., 2020), rams (Banday, Lone, Rasool, Rashid \& Shikari, 2017), buffalo (El-Khawagah, Kandiel, \& Samir, 2020), and dogs (Kawasaki et al., 2020), and the inclusion of BHT improved cryopreserved sperm parameters in cats (Jara et al., 2019), dogs (Sun et al., 2020), boars (Trzcińska, Bryła, Gajda, \& Gogol, 2015), goats (Memon et al., 2011), and bulls (Shoae, \& Zamiri, 2008), in the present study, these substances were not able to produce better sperm motility parameters or $\mathrm{PMI}$ in ram semen stored at 5 ${ }^{\circ} \mathrm{C}$ or frozen-thawed. 
Table 4

Sperm parameters of ram sperm cooled for $24 \mathrm{~h}$ at $5^{\circ} \mathrm{C}$ in BotuBov ${ }^{\circledR}$ containing different concentrations of BHT and DMSO

\begin{tabular}{|cccccccc|}
\hline & Control & BHT1 & BHT2 & BHT3 & DMSO3 & DMSO4 & P value \\
\hline TM (\%) & $88.5 \pm 6.4$ & $88.6 \pm 7.9$ & $88.3 \pm 6.9$ & $88.3 \pm 7.5$ & $87.6 \pm 8.2$ & $87.2 \pm 8.9$ & 0.904 \\
\hline PM (\%) & $59.4 \pm 10.6$ & $62.3 \pm 8.9$ & $60.3 \pm 9.2$ & $59.7 \pm 9.2$ & $58.6 \pm 9.0$ & $59.5 \pm 8.6$ & 0.752 \\
\hline RAP (\%) & $77.9 \pm 9.7$ & $79.9 \pm 9.7$ & $78.0 \pm 8.6$ & $78.1 \pm 9.8$ & $77.6 \pm 9.6$ & $76.9 \pm 10.4$ & 0.871 \\
\hline VAP $(\mu \mathrm{m} / \mathrm{s})$ & $126.7 \pm 10.6$ & $127.0 \pm 11.3$ & $123.3 \pm 10.1$ & $125.5 \pm 12.5$ & $124.4 \pm 9.7$ & $124.3 \pm 9.5$ & 0.744 \\
\hline VSL $(\mu \mathrm{m} / \mathrm{s})$ & $109.0 \pm 11.5$ & $109.8 \pm 11.3$ & $106.5 \pm 9.6$ & $108.2 \pm 11.9$ & $106.9 \pm 10.1$ & $107.6 \pm 8.5$ & 0.842 \\
\hline VCL $(\mu \mathrm{m} / \mathrm{s})$ & $195.6 \pm 26.1$ & $196.4 \pm 26.3$ & $192.3 \pm 25.7$ & $189.5 \pm 46.0$ & $194.5 \pm 28.1$ & $192.1 \pm 26.9$ & 0.960 \\
\hline PMI $(\%)$ & $57.4 \pm 18.2$ & $56.5 \pm 18.7$ & $56.8 \pm 17.6$ & $57.4 \pm 16.9$ & $53.9 \pm 20.2$ & $55.8 \pm 18.3$ & 0.985 \\
\hline
\end{tabular}

$T M$, total motility; $P M$, progressive motility; VAP, average path velocity; VSL, velocity straight line; VCL, velocity curvilinear; RAP, rapid sperm; PMl, plasma membrane integrity. Control, egg yolk-based extender without BHT (BotuBov $\left.{ }^{\circledR}\right) ; B H T 1$, BotuBov $^{\circledR}$ containing $0.5 \mu \mathrm{g}$ of $\mathrm{BHT} / \mathrm{mL}+0.375 \mu \mathrm{L}$ of DMSO$/ \mathrm{mL}$; BHT2, BotuBov ${ }^{\circledR}$ containing $1.0 \mu \mathrm{g}$ of BHT/mL +0.750 $\mu \mathrm{L}$ of DMSO/mL; BHT3, BotuBov ${ }^{\circledR}$ containing $1.5 \mu \mathrm{g}$ of $\mathrm{BHT} / \mathrm{mL}+1.125 \mu \mathrm{L}$ of DMSO $/ \mathrm{mL}$; DMSO3, BotuBov ${ }^{\circledR}$ containing $0.375 \mu \mathrm{L}$ of DMSO $/ \mathrm{mL}$; DMSO4, BotuBov ${ }^{\circledast}$ containing $1.125 \mu \mathrm{L}$ of DMSO $/ \mathrm{mL}$. All data are presented as the mean \pm SD.

\section{Table 5}

\section{Sperm parameters of post-thawed ram sperm extended and frozen in BotuBov ${ }^{\circledR}$ containing different} concentrations of BHT and DMSO

\begin{tabular}{|cccccccc|}
\hline & Control & BHT1 & BHT2 & BHT3 & DMSO3 & DMSO4 & P value \\
\hline TM (\%) & $68.7 \pm 13.9$ & $69.8 \pm 11.4$ & $68.9 \pm 13.8$ & $70.3 \pm 12.3$ & $68.8 \pm 14.7$ & $64.9 \pm 14.3$ & 0.849 \\
\hline PM (\%) & $36.8 \pm 10.2$ & $35.6 \pm 9.4$ & $36.2 \pm 9.6$ & $37.2 \pm 9.8$ & $36.3 \pm 11.2$ & $33.6 \pm 9.7$ & 0.849 \\
\hline RAP (\%) & $47.7 \pm 14.0$ & $47.9 \pm 12.9$ & $47.5 \pm 13.6$ & $49.1 \pm 14.4$ & $47.6 \pm 14.4$ & $43.9 \pm 13.6$ & 0.841 \\
\hline VAP $(\mu \mathrm{m} / \mathrm{s})$ & $106.5 \pm 15.2$ & $106.7 \pm 13.8$ & $106.6 \pm 14.4$ & $107.1 \pm 16.4$ & $106.7 \pm 17.1$ & $103.9 \pm 12.2$ & 0.972 \\
\hline VSL $(\mu \mathrm{m} / \mathrm{s})$ & $92.0 \pm 14.4$ & $90.4 \pm 12.7$ & $91.7 \pm 14.5$ & $91.6 \pm 15.3$ & $90.3 \pm 13.2$ & $89.7 \pm 12.3$ & 0.993 \\
\hline VCL $(\mu \mathrm{m} / \mathrm{s})$ & $159.4 \pm 23.1$ & $163.9 \pm 19.3$ & $160.1 \pm 19.4$ & $163.5 \pm 22.9$ & $160.8 \pm 20.1$ & $160.9 \pm 17.7$ & 0.909 \\
\hline PMI $(\%)$ & $33.1 \pm 16.9$ & $32.6 \pm 16.3$ & $28.5 \pm 14.3$ & $29.4 \pm 15.3$ & $30.9 \pm 15.6$ & $28.9 \pm 13.6$ & 0.842 \\
\hline
\end{tabular}

TM, total motility; PM, progressive motility; VAP, average path velocity; VSL, velocity straight line; TM, total motility; PM, progressive motility; VAP, average path velocity; VSL, velocity straight line; VCL, velocity curvilinear; RAP, rapid sperm; PMI, plasma membrane integrity. Control, egg yolk-based extender without $\mathrm{BHT}$ (BotuBov ${ }^{\circledR}$ ); BHT1, BotuBov ${ }^{\circledR}$ containing $0.5 \mu \mathrm{g}$ of $\mathrm{BHT} / \mathrm{mL}+0.375 \mu \mathrm{L}$ of DMSO/mL; BHT2, BotuBov ${ }^{\otimes}$ containing $1.0 \mu \mathrm{g}$ of BHT/mL $+0.750 \mu \mathrm{L}$ of DMSO/mL; BHT3, BotuBov $^{\circledast}$ containing $1.5 \mu \mathrm{g}$ of $\mathrm{BHT} / \mathrm{mL}+1.125 \mu \mathrm{L}$ of DMSO $/ \mathrm{mL}$; DMSO3, BotuBov ${ }^{\circledast}$ containing $0.375 \mu \mathrm{L}$ of $\mathrm{DMSO} / \mathrm{mL}$; DMSO4, BotuBov ${ }^{\circledR}$ containing $1.125 \mu \mathrm{L}$ of $\mathrm{DMSO} / \mathrm{mL}$. All data are presented as the mean \pm SD.

It is well known that sperm motility parameters and fertility are negatively affected by the overproduction of ROS and membrane lipid peroxidation, and findings from previous studies demonstrated that these antioxidants prevent sperm damage caused by oxidative stress (Guthrie\&Welch, 2012). However, similar to our results, other studies have also shown no beneficial effect of including quercetin or BHT on motility parameters of cryopreserved 
semen from bulls, rabbits, buffalo (Avdatek et al., 2018; Johinke \& Bathgate, 2014; ljaz, Hussain, Aleem, Yousaf, \& Rehman, 2009), and ram sperm (Silva, Cajueiro, Silva, Soares, \& Guerra, 2012; Watson, \& Anderson, 1983). It is important to note that the inclusion of DMSO was tested at the lowest and highest concentrations used as a solvent for both quercetin and $\mathrm{BHT}$ in the present study and it did not produce any beneficial or adverse effects on sperm parameters. Although DMSO has been used for semen cryopreservation in other species (e.g., turkey, pheasant, redtailed hawk, sandhill crane, Indian red jungle fowl, Peregrine falcon) (Rakha et al., 2018; laffaldano et al., 2016; Herrera, Quintana, Lopez, Betancourt, \& Fierro, 2005; Gee, Baskt, \& Sexton, 1985), higher concentrations of DMSO can lead to ultrastructural damage of the sperm membrane (Gurtovenko \& Anwar, 2007). Therefore, the doses tested in the present study were safe for ram sperm.

Contradictory results using antioxidants for sperm cryopreservation are common in the literature (Banday et al., 2017; Silva et al., 2012; Sikka, 2004). However, the authors assumed that the differences in experimental methodology, the composition of the extender, and animal species may have affected these results. Interestingly, ram sperm is highly vulnerable to oxidative stress because of the high polyunsaturated fatty acid content in the plasma membrane (Bucak et al., 2010). Therefore, the antioxidants tested in the present study may not have sufficient action to overcome oxidative stress in this species. Quercetin inhibits ROS formation by enzymatic and non-enzymatic systems (e.g., NADPH oxidase, NADH-dependent oxidoreductase) (Li, 2011; Delmas, Jannin, \& Latruffe., 2005), while BHT converts the peroxy radicals to hydroperoxides, thereby interrupting the development of oxidative processes (Seifi-Jamadi et al., 2016). Although Banday et al. (2017) reported a beneficial effect of quercetin on sperm motility in ram cryopreserved semen diluted in Tris extender, these authors reported that taurine at $40 \mathrm{mM}$ produced better results than the other tested antioxidants (e.g., quercetin and glutathione). Interestingly, taurine is neither a classical scavenger nor a regulator of antioxidative defenses; it protects the mitochondria against excessive superoxide generation by regulating mitochondrial protein synthesis (Holt, 1997). Therefore, different antioxidant mechanisms of action or a synergistic effect may improve the regulation of oxidative stress in this species and should be tested in future studies.

Another difference that should be noted is that an egg yolk-based extender with an undefined composition (BotuBov ${ }^{\circledR}$ ) was used for processing ram semen in the present study. In contrast, quercetin and $\mathrm{BHT}$ were added to a Tris extender in previous studies. The composition of the extender is a factor that could impact the results presented here, because sperm parameters were not affected after cooling at $5^{\circ} \mathrm{C}$ for 24 $h$, even in the control group. However, it is not possible to discern the composition of the extender used in the present study because it is a commercially available extender with a protected composition.

\section{Conclusions}

These results suggest that the commercially available extender BotuBov ${ }^{\circledR}$ effectively protects ram sperm against cold 
shock during liquid storage at $5^{\circ} \mathrm{C}$ for up to 24 h. However, the inclusion of quercetin or BHT in BotuBov ${ }^{\circledR}$ does not enhance sperm motility and $\mathrm{PMI}$ of ram sperm subjected to cooling at $5{ }^{\circ} \mathrm{C}$ for $24 \mathrm{~h}$ or freezing processes. Further studies are needed to assess the fertility rates of cooled or frozen-thawed ram semen with the inclusion of BHT and quercetin.

\section{Conflicts of interest}

The authors declare no conflict of interest.

\section{Acknowledgments}

This study was supported by the São Paulo State Research Foundation (FAPESP grant \#2012/50277-6).

\section{References}

Allai, L., Druart, X., Öztürk, M., BenMoula, A., Nasser, B., \& Amiri, B. (2016). Protective effects of Opuntia ficus-indica extract on ram sperm quality, lipid peroxidation and DNA fragmentation during liquid storage. Animal Reproduction Science, 175, 1-9. doi: 10.1016/j.anireprosci.2016.09.013

Amidi, F., Pazhohan, A., Shabani, N. M. Khodarahmian, M., \& Nekoonam, S. (2016). The role of antioxidants in sperm freezing: a review. Cell and Tissue Banking, 17(4), 745-756. doi: 10.1007/s10561-016-95 $66-5$

Appiah, M. O., Li, W., Zhao, J., Liu, H., Dong, Y., Xiang, J.,... Lu, W. (2020). Quercetin supplemented casein-based extender improves the post-thaw quality of rooster semen. Cryobiology, 94, 57-65. doi: 10. 1016/j.cryobiol.2020.04.010

Avdatek, F., Yeni, D., İnanç, M. E., Çil, B., Tuncer, B. P., Turkmen, R., \& Tasdemir, U. (2018). Supplementation of quercetin for advanced DNA integrity in bull semen cryopreservation. Andrologia, 50(4), 1-7. doi: 10.1111/and.12975

Banday, M. N., Lone, F. A., Rasool, F., Rashid, M., \& Shikari, A. (2017). Use of antioxidants reduce lipid peroxidation and improve quality of crossbred ram sperm during its cryopreservation. Cryobiology, 74, 2530. doi: 10.1016/j.cryobiol.2016.12.008

Ben, A. F., Zribi, N., \& Ammar-Keskes, L. (2011). Antioxidative potential of Quercetin against hydrogen peroxide induced oxidative stress in spermatozoa in vitro. Andrologia, 43(4), 261-265. doi: 10.1111/j. 1439-0272.2010.01063.x

Boots, A. W., Haenen, G. R. M. M., \& Bast, A. (2008). Health effects of quercetin: from antioxidant to nutraceutical. European Journal of Pharmacology, 585(2-3), 325337. doi: 10.1016/j.ejphar.2008.03.008

Brito, L. F. C. (2007). Evaluation of stallion sperm morphology. Clinical Techiniques in Equine Practice, 6(4), 249-264. doi: 10.1053/j.ctep.2007.09.004

Bucak, M. N., Sariözkan, S., Tuncer, P. B., Sakin, F., Atessahin, A., Kulakisiz, R., \& Çevik, M. (2010). The effect of antioxidants on post-thawed Angora goat (Capra hircus ancryrensis) sperm parameters, lipid peroxidation and antioxidant activities. Small Ruminant Research, 89(1), 24-30. doi: 10.1016/j.smallrumres.2009.11.015

Budai, C., Egerszegi, I., Olah, J., Javor, A., \& Kovacs, A. (2014). The protective effect 
of antioxidants on liquid and frozen stored ram semen. Scientific Papers Animal Science and Biotechnologies, 47(1), 4652.

Delmas, D., Jannin, B., \& Latruffe, N. (2005). Resveratrol: preventing properties against vascular alterations and ageing. Molecular Nutrition \& Food Research, 49(5), 377-395. doi: 10.1002/ mnfr.200400098

El-Khawagah, A. R. M., Kandiel, M. M. M., \& Samir, H. (2020). Effect of quercetin supplementation in extender on sperm kinematics, extracellular enzymes release, and oxidative stress of Egyptian buffalo bulls frozen thawed semen. Frontiers in Veterinary Science, 7. doi: 10. 3389/fvets.2020.604460

Fidan, A., Yeni, D., Avdatek, F., Özçinar, U., \& Hazman, O. (2018). Changes in oxidative stress markers during electro-ejaculation procedure in merino rams. Jornal of the Hellenic Veterinary Medical Society, 68(3), 479-486. doi: 10.12681/jhvms. 15544

Gee, G. F., Baskt, M. R., \& Sexton, S. F. (1985). Cryogenic preservation of semen from the greater sandhill crane. Jornal of Wildlife Management, 49(2), 480-484.

Gibb, Z., Butler, T. J., Morris, L. H. A., Maxwell, W. M. C., \& Grupen, C. G. (2013). Quercetin improves the postthaw characteristics of cryopreserved sexsorted and nonsorted stallion sperm. Theriogenology, 79(6), 1001-1009. doi: 10.1016/j.theriogenology.2012.06.032

Guardia, T., Rotelli, A. E., Juarez, A. O., \& Pelzer, L. E. (2001). Anti-inflammatory properties of plant flavonoids. Effects of rutin, quercetin and hesperidin on adjuvant arthritis in rat. Farmaco, 56(9), 683-687. doi: 10.1016/S0014-827X(01)01111-9

Gurtovenko,A.A.,\&Anwar, J.(2007). Modulating the structure and properties of cell membranes: the molecular mechanism of action of dimethyl sulfoxide. Journal of Physical Chemistry Biochem, 111(35), 10453e60. doi: 10.1021/jp073113e

Guthrie, H. D., \& Welch, G. R. (2012). Effects of reactive oxygen species on sperm function. Theriogenology, 78(8), 17001708. doi: 10.1016/j.theriogenology.20 12.05 .002

Harrison, R. A. P., \& Vickers, S. E. (1990). Use of fluorescent probes to assess membrane integrity in mammalian spermatozoa. Journal of Reproduction and Fertility, 88(1), 343-352. doi: 10.1530/jrf.0.088 0343

Herrera, J. A., Quintana, J. A., Lopez, M. A., Betancourt,M.,\&Fierro,R.(2005).Individual cryo-preservation with dimethyl sulfoxide and polyvinylpyrrolidone of ejaculates and pooled semen of three avian species. Archives of Andrology, 51(5), 353-360. doi: 10.1080/014850190944401

Holt, W. V. (1997). Alternative strategies for the long-term preservation of spermatozoa. Reproduction, Fertility and Development, 9(3), 309-319. doi: 10.1071/R96082

laffaldano, N., Di lorio, M., Miranda, M., Zaniboni, L., Manchisi, A., \& Cerolini, S. (2016). Cryopreserving Turkey semen in straws and nitrogen vapour using DMSO or DMA: effects of cryoprotectant concentration, freezing rate and thawing rate on post-thaw semen quality. British Poultry Science, 57(2), 264-270. doi: 10. 1080/00071668.2016.1148261 
ljaz, A., Hussain, A., Aleem, M., Yousaf, M. S., \& Rehman, H. (2009). Butylated hydroxytoluene inclusion in semen extender improves the post-thawed semen quality of Nili-Ravi buffalo (Bubalus bubalis). Theriogenology, 71(8), 1326-1329. doi: 10.1016/j. theriogenology.2008.12.023

Jara, B., Merino, O., Sánchez, R., \& Risopatrón, J. (2019). Positive effect of butylated hydroxytoluene $(\mathrm{BHT})$ on the quality of cryopreserved cat spermatozoa. Cryobiology, 89, 76-81. doi: 10.1016/j. cryobiol.2019.05.003

Johinke, D., \& Bathgate, R. (2014). Quercetin reduces the in vitro production of $\mathrm{H} 2 \mathrm{O} 2$ during chilled storage of rabbit spermatozoa. Animal Reproduction Science, 151(3-4), 208-219. doi: 10.10 16/j.anireprosci. 2014.10.017

Kawasaki, Y., Sakurai, D., Yoshihara, T., Tsuchida, M., Harakawa, S., \& Suzuki, H. (2020). Effect of quercetin on the motility of cryopreserved canine spermatozoa. Cryobiology, 96, 50-54. doi: 10.1016/j. cryobiol.2020.08.006

Li, Y. (2011). Antioxidants in biology and medicine: essentials, advances and clinical applications. Blacksburg (Virgínia): Nova Science Publishers.

Mandiki, S. N. M., Derycke, G., Bister, J. L., \& Paquay, R. (1998). Influence of season and age on sexual maturation parameters of Texel, Suffolk and lle-de-France rams 1. Testicular size, semen quality and reproductive capacity. Small Ruminant Research, 28(1), 67-79. doi: 10.1016/ s0921-4488(97)00073-4
Memon, A. A., Wahid, H., Rosnina, Y., Goh, Y. M., Ebrahimi, M., Nadia, F. M., \& Audrey, G. (2011). Effect of butylated hydroxytoluene on cryopreservation of Boer goat semen in Tris egg yolk extender. Animal Reproduction Science, 129(1-2), 44-49. doi: 10.1016/j.anireprosci.2011.10.004

Merino, O., Aguagüiña, W. E., Esponda, P., Risopatrón, J., Isachenko, E., Isachenko, V., \& Sánchez, R. (2015). Protective effect of butylated hydroxytoluene on sperm function in human spermatozoa cryopreserved by vitrification technique. Andrologia, 47(2), 186-193. doi: 10.1111/ and. 12246

Neagu, V. R., García, B. M., Sandoval, C. S., Rodríguez, A. M., Ferrusola, C. O., Fernández L. G.,... Peña, F. J. (2010). Freezing dog semen in presence of the antioxidant butylated hydroxytoluene improves postthaw sperm membrane integrity. Theriogenology, 73(5), 645650. doi: 10.1016/j.theriogenology.2009. 10.021

Nitiema, L. W., Savadogo, A., Simpore, J., Dianou, D., \& Traore, A. S. (2012). In vitro antimicrobial activity of some phenolic compounds (coumarin and quercetin) against gastroenteritis bacterial strains. International Journal of Microbiological Research, 3(3), 183-187. doi: 10.5829/ idosi.ijmr.2012.3.3

Oliveira, M. A.D., Oliveira, R., Lima, A., Andrade, E., Abreu, J., \& Oliveira, F. (2017). Physical evaluation, morphological and identification of seminal proteins in Santa Ines sheep. Revista Brasileira Saúde e Produção Animal, 18(1), 211-220. doi: 10.1590/S1519-99402017000100020 
Palomo, M. J., García, W., \& Tabarez, G. (2017). Effect of seminal plasma and butylated hydroxytoluene (BHT) concentration on ram sperm freezability. Small Ruminant Research, 153, 66-70. doi: 10.1016/j. smallrumres.2017.05.010

Parks, J. E., \& Lynch, D. V. (1992). Lipid composition and thermotropic phase behavior of boar, bull, stallion, and rooster sperm membranes. Cryobiology, 29(2), 255-266. doi: 10.1016/0011-2240 (92)900 24-V

Rakha, B. A., Ansari, M. S., Akhter, S., Zafar, Z., Naseer A., Hussain, I., Santiago-Moreno, J. (2018). Use of dimethylsulfoxide for semen cryopreservation in Indian red jungle fowl (Gallus gallus murghi). Theriogenology, 122, 61-67. doi: 10.10 16/j.theriogenology.2018.09.003

Salamon, S., \& Maxwell, W. M. C. (2000). Storage of ram semen. Animal Reproduction Science, 62(1-3), 77-111. doi: 10.1016/ S0378-4320(00)00155-X

Seifi-Jamadi, A., Kohram, H., Zareh-Shahne, A., Dehghanizadeh, P., \& Ahmad, E. (2016). Effect of various concentrations of butylated hydroxyanisole and butylated hydroxytoluene on freezing capacity of Turkman stallion sperm. Animal Reproduction Science, 170(july), 108113. doi: 10.1016/j.anireprosci.2016.04. 010

Shoae, A., \& Zamiri, M. J. (2008). Effect of butylated hydroxytoluene on bull spermatozoa frozen in egg yolk-citrate extender. Animal Reproduction Science, 104(2-4), 414-418. doi: 10.1016/j. anireprosci.2007.07.009
Sikka, S. C. (2004). Role of oxidative stress and antioxidants in andrology and assisted reproductive technology. Journal of Andrology, 25(1), 5-18. doi: 10.1002/j. 1939-4640.2004.tb02751.x

Silva, E. C. B., Cajueiro, J. F. P., Silva, S. V., Soares, P. C., \& Guerra, M. M. P. (2012). Effect of antioxidants resveratrol and quercetin on in vitro evaluation of frozen ram sperm. Theriogenology, 77(8), 1722-1726. doi: 10.1016/j.theriogenology.2011.11.023

Sun, L., Wu, C., Xu, J., Zhang, S., Dai, J., \& Zhang, D. (2020). Addition of butylated hydroxytoluene (BHT) in tris-based extender improves post-thaw quality and motion dynamics of dog spermatozoa. Cryobiology, 97, 71-75. doi: 10.1016/j. cryobiol.2020.10.006

Trzcińska, M., Bryła, M., Gajda, B., \& Gogol, P. (2015). Fertility of boar semen cryopreserved in extender supplemented with butylated hydroxytoluene. Theriogenology, 83(3), 307-313. doi: 10. 1016/j. theriogenology.2014.07.045

Tvrdá, E., Tušimová, E., Kováčik, A., Paál, D., \& Lukáč, N. (2016). Protective effects of quercetin on selected oxidative biomarkers in bovine spermatozoa subjected to ferrous ascorbate. Reproduction in Domestic Animals, 51(4), 524-537. doi: 10.1111/rda.12714

Watson, P. F., \& Anderson, W. J. (1983). Influence of butylated hydroxytoluene (BHT) on the viability of ram spermatozoa undergoing cold shock. Journal of Reproduction and Fertility, 69(1), 229235. doi: 10.1530/jrf.0.0690229 
